\title{
Mathematical modeling to optimize pine lumber yield ${ }^{1}$
}

\author{
Eraldo Antonio Bonfatti Júnior $\circledast^{2 *}$ Elaine Cristina Lengowski@ ${ }^{3}$ Tamires de Almeida Sfeir $\circledast^{2}$ Bruno \\ Gruber Nisponginsk $\oplus^{4}$ Kaio Fanes ${ }^{4}{ }^{4}$ Kauana Melissa Cunha Dickow ${ }^{4}$
}

${ }^{1}$ Selected from the IV Brazilian Congress of Wood Science and Technology

${ }^{2}$ Universidade Federal do Paraná, Av. Pref. Lothário Meissner, 632, Jardim Botânico, Campus III, CEP 80210-170, Curitiba, PR, Brasil

${ }^{3}$ Universidade Federal do Mato Grosso, Av. Fernando Corrêa da Costa, 2367, Boa Esperança, CEP 78060-900, Cuiabá, MT, Brasil

${ }^{4}$ Universidade do Contestado, Rua Wendelin Metzger, SN, Distrito de Marcílio Dias CEP 89460-010, Canoinhas, SC Brasil

\section{Original Article \\ *Corresponding author: bonfattieraldo@gmail.com \\ Keywords: \\ Linear Programming \\ Operational Research \\ Demand \\ Sawmill}

Palavras-chave:

Programação linear

Pesquisa Operacional

Demanda

Serraria

Received in

2019/05/12

Accepted on

2019/11/12

Published in

2020/04/03

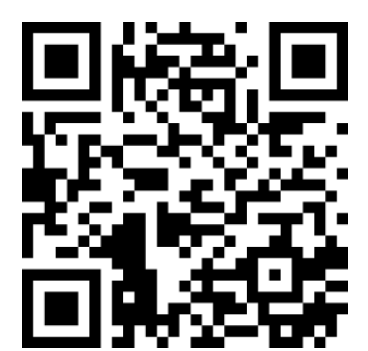

DOI:http://dx.doi.org/10.340 62/afs.v7i1.9767

\section{(cc) BY}

ABSTRACT: In Brazil, only 4\% of the 7.84 million hectares of planted forests is devoted to the production of lumber wood, being in Santa Catarina state most of the wood used for this purpose is of the Pinus genus. This work aims to estimate the maximum utilization of logs due to the production of wood boards in the city of Canoinhas, Santa Catarina. For that, a sawmill of the region were consulted and the dimensions of the pieces produced were verified. The dimensions and classes of logs commonly traded in the region were also raised. As a result, 82 models were created in Maxitora software in diagram format. With the cutting models the sawmill had its performance optimized with the use of techniques of operational research in a cutting problem. The whole linear programming technique was used for an estimated demand for the quantity of each of the pieces produced. The results showed that only five models are required to meet such demand, so the yield is $43.18 \%$.

\section{Modelagem matemática para otimização da produção de madeira serrada de Pinus}

RESUMO: No Brasil, apenas 4\% dos 7,84 milhões de hectares de florestas plantadas é destinado a produção de madeira serrada, sendo que no estado de Santa Catarina a maior parte da madeira para este fim é do gênero Pinus spp. Esse trabalho teve como objetivo estimar o máximo aproveitamento de toras em função da produção de tábuas na cidade de Canoinhas, Santa Catarina. Para isso foi consultada uma serraria da região e verificadas as dimensões das peças produzidas. Também foram levantadas as dimensões e classes de toras comumente comercializadas na região. Em função disto, foram criados 82 modelos de padrões de corte no software MaxiTora em formato de diagrama. Com os modelos de cortes a serraria teve seu rendimento otimizado com o uso de técnicas de pesquisa operacional em um problema de corte. Criou-se um modelo de programação linear inteira, para uma demanda estimada da quantidade de cada uma das peças produzidas. Os resultados demonstraram que são necessários apenas cinco modelos para suprir tal demanda, de modo que o rendimento seja de $43,18 \%$ 


\section{Bonfatti Júnior et al.}

\section{Introduction}

The interest in the use of fast growing species, as a source of raw material for obtaining lumber wood, has increased significantly. The restrictions imposed on the use of wood from native forests have been identified as one of the main factors that led to the search for species of fast growth to meet the demand of the wood industry (Tomaselli, 2000). Among the genera that show rapid growth are Eucalyptus and Pinus (IBÁ, 2019).

In Brazil, only $4 \%$ of the 7.84 million hectares of planted forest are destined for solid wood products, where the consumption of wood in $\operatorname{logs}$ was 33.58 million $\mathrm{m}^{3}$ for the production of lumber wood, of which 27.37 million $\mathrm{m}^{3}$ are pine wood (IBÁ, 2019).

Due to the favorable growth conditions and for presenting logs of good workability in the unfolding, the Santa Catarina solid wood industry is based on the use of pine wood (Murara Junior et al., 2013). Santa Catarina is one of the brazilian states with great prominence in the export of lumber wood, being that $48 \%$ of the exported pine lumber wood comes from this state (ACR, 2019).

The lumber wood yield is influenced by several factors, such as species characteristics, products, machinery, labor and, mainly, by the diameter of the logs. In addition to these factors, the treatment that is given to the logs still in the sawmill yard and other decisions on how to deploy them are fundamental factors for achieving good levels of yield (Vital, 2008; Murara Júnior et al., 2013). In this context, modeling and operational planning are tools that help in choosing the best splitting technique and increasing log yield (Murara Júnior et al., 2005; Heinrich, 2010).

MaxiTora is a software that assists in the definition of the cutting model and a preview of the products and yields obtained for the various diametric classes processed in a sawmill. (Lengowski et al., 2017). Operational research is an interdisciplinary field whose contemporary interest is the study of analytical methods for decision making, in a broad sense (Hillier \& Lieberman, 2012). Among the various topics of interest in operational research, linear programming plays a central role due to its wide applicability in real situations and the existence of efficient methods for solving large problems (Arenales \& Armentano, 2015).

Cutting problems consist to cut large pieces in order to produce smaller piece to meet a certain demand and, concurrently, optimizing a certain objective function (Poldi \& Arenales, 2010). In this context, the objective of this work is to optimize the cutting of pine logs seeking to maximize the sawmill yield in function of wood board kind produced in the region of Canoinhas through mathematical models.

\section{Material and Methods \\ Wood boards and diametric logs classes}

Through research at sawmills in the study region, the main wood types of wood boards that would be produced to generate the cutting models were defined (Table 1), and the logs diametric classes were defined according to the availability of logs offered in the region, described in Table 2.

Table 1. Main dimensions of wood boards produced and their monthly demands.

\begin{tabular}{ccccc}
\hline $\begin{array}{c}\text { Wood } \\
\text { board }\end{array}$ & Width $(\mathbf{m m})$ & Thickness $(\mathbf{m m})$ & Length $(\mathbf{m m})$ & $\begin{array}{c}\text { Demand (number of wood } \\
\text { boards) }\end{array}$ \\
\hline 1 & 77 & 27 & 2130 & 1500 \\
2 & 85 & 27 & 2130 & 2700 \\
3 & 125 & 27 & 2130 & 4500 \\
4 & 125 & 37 & 2130 & 2000 \\
\hline
\end{tabular}

Table 2. Diametric logs classes and price of $\log _{s}$ offered in the study region.

\begin{tabular}{ccc}
\hline Class & Diameter $(\mathbf{c m})$ & Price per ton of each logs class $(\mathbf{R} \$)$ \\
\hline A & $13.0-17.0$ & 85 \\
B & $17.1-21.0$ & 118 \\
C & $21.1-25.0$ & 118 \\
D & $25.1-29.0$ & 141 \\
E & $29.1-32.0$ & 141 \\
F & $32.1-35$ & 141 \\
G & $35.1-40$ & 200 \\
\hline
\end{tabular}

Optimized sawing

The optimization of the sawing simulation was performed with the MaxiTora software. The four types of pieces were registered (Table 1) considering the seven classes of logs (Table 2). The adopted considerations were $2 \mathrm{~mm}$ of thickness of the vertical saw and $2 \mathrm{~mm}$ in the horizontal saw, and a percentage of $5 \%$ of bark, obeying the free 
optimization made to increase the yield. As a result, 82 diagrams models were created in the MaxiTora software.

\section{Mathematical modeling}

With the performance of each sawing model obtained by the MaxiTora software, sawmill performance was optimized based on operational research to find the models that would make it possible to obtain the parts demanded with the maximization of yield in a single period situation.

An entire linear programming model was created, which consists of defining the objective function and technical constraints. The LINGO 17.0 software was used to solve the model.

The following is the terminology used to define the model expressions mathematically.

Sets and parameters used.

$I=\{1, \ldots,|i|\} \quad$ Cutting models set

$J=\{1, \ldots,|j|\} \quad$ Set of wood boards

$V i \quad$ Yield of the cutting model $i$

$D j \quad$ Demand for the type of wood board $j l$

$q j i \quad$ Number of wood boards $j$ produced by the cutting model $i$

After describing the sets and parameters, the decision variable is defined.

$x i \quad$ Model processed quantity $i$

Then the mathematical model is defined.

$$
\begin{aligned}
& \operatorname{Max}(Z)=\sum_{i} V_{i} x_{i} \\
& \sum_{i} q_{j i} x_{i}=D_{j} \quad \forall j \\
& x_{i} \in \mathbb{Z}+
\end{aligned}
$$

The objective function (equation 1) maximizes cutting process yield, obtained by multiplying the yield of each cutting model by the number of times each model will be run. The objective function is subject to the satisfaction of the set of restrictions (equation 2) that aim to meet the demand for each type of wood board.

Acting together with these restrictions are the non-negativity and integrity restrictions (equation 3), so the system must have values greater than or equal to zero and integers.

\section{Results and discussion}

According to the result of the entire linear programming to reach the demand through the imposed restrictions, five cut models were selected: 1, 9, 10, 58 and 71, the diagrammatic representations are shown in Figure 1 and the yields and wood boards numbers of each model is shown in Table 3 . The optimal yield given by the objective function $(\operatorname{Max}(Z))$ was $43.18 \%$, in line with the typical yields of a Pinus spp. sawmill in the region (Lengowski et al., 2017).

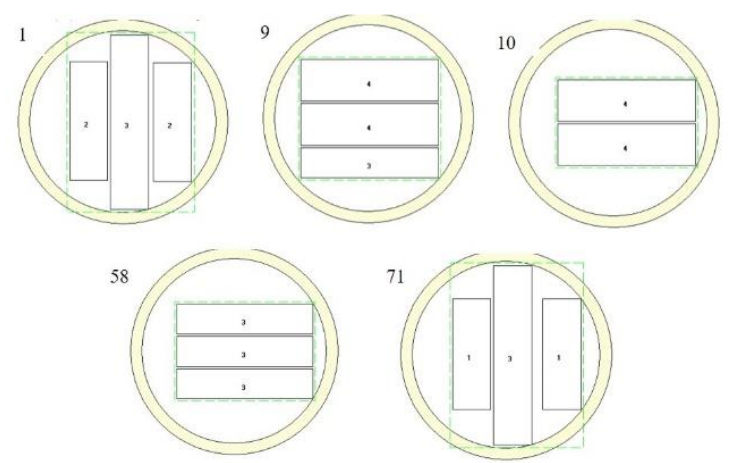

Figure 1. Cutting diagrams of the models selected by linear programming.

All diametric logs classes showed satisfactory yields, however class A and class B were selected for production, with 2100 class A and 1467 class B logs. The selection of Model 10 to be runned only once is due to the need for only two type 4 wood boards to complete the demand for this type of wood board, a common situation in problems of optimization of single-period cutting processes (Ulbrich \& Ribeiro, 2010), but which can be avoided when considering multiperiod demand (Poldi \& Arenales, 2010).

The selected diametric logs classes have smaller diameters compared to the others, therefore they have a lower cost per ton in the market, as shown in Table 2. As the product has a low added value and without structural use, the use of logs with a smaller diameter, which consequently presented higher percentage of juvenile wood, will not result in quality problems.

Each model will run for a certain number of times, that is, the number of $\operatorname{logs}$ to be processed to reach the required demand are shown in Table 4.

Operational research tools, especially linear programming problems, are effective in complex optimization problems (Ulbrich \& Ribeiro, 2010). In the present study, the sawmill would not only have better yield but also the minimization of its costs because the linear programming model indicated the use of the lowest cost diametric logs classes. Another aspect is that when the sawmill company is also the owner of forest massifs, the harvest period can be anticipated, since by using smaller logs, the option is to cut down younger trees.

\section{Conclusions}

It can be concluded through mathematical models that:

- Optimal performance will be achieved with $150 \mathrm{~mm}$ (class A) and 190mm (class B) diameter logs, leaving less waste, consequently increasing production and having a lower cost considering the purchase of logs from third parties.

- With a yield of $43.18 \%$, the defined model was able to meet all the restrictions imposed, in addition to finding the optimal deployment option. 


\section{Bonfatti Júnior et al.}

Table 3. The models selected with the respective yields, generated parts and the diametric classes.

\begin{tabular}{lllllll}
\hline \multirow{2}{*}{ Models } & \multirow{2}{*}{ Yield } & \multicolumn{4}{c}{ Produced wood boards } & \multirow{2}{*}{ Diametric logs class } \\
\cline { 3 - 6 } & & $\mathbf{1}$ & $\mathbf{2}$ & $\mathbf{3}$ & $\mathbf{4}$ & $\mathrm{A}$ \\
Model 1 & $45.07 \%$ & 0 & 2 & 1 & 0 & $\mathrm{~B}$ \\
Model 9 & $35.71 \%$ & 0 & 0 & 3 & 0 & $\mathrm{~B}$ \\
Model 10 & $32.62 \%$ & 0 & 0 & 0 & 2 & $\mathrm{~B}$ \\
Model 58 & $44.53 \%$ & 0 & 0 & 1 & 2 & $\mathrm{~A}$ \\
Model 71 & $42.63 \%$ & 2 & 0 & 1 & 0 & \\
\hline
\end{tabular}

Table 4. Number of logs processed per model and the respective number of wood boards.

\begin{tabular}{lccccc}
\hline \multirow{2}{*}{ Models } & Number of logs & \multicolumn{4}{c}{ Number of wood boards } \\
\cline { 3 - 6 } & & Board 1 & Board 2 & Board 3 & Board 4 \\
\hline Model 1 & 1350 & 0 & 2700 & 1350 & 0 \\
Model 9 & 467 & 0 & 0 & 1401 & 0 \\
Model 10 & 1 & 0 & 0 & 0 & 2 \\
Model 58 & 999 & 0 & 0 & 999 & 1998 \\
Model 71 & 750 & 1500 & 0 & 750 & 0 \\
\hline Total & $\mathbf{3 5 6 7}$ & $\mathbf{1 5 0 0}$ & $\mathbf{2 7 0 0}$ & $\mathbf{4 5 0 0}$ & $\mathbf{2 0 0 0}$ \\
\hline
\end{tabular}

\section{Acknowledgements}

The authors would like to thank the company OpTimber for the license granted to use the Maxitora software and Dallo Madeiras LTDA for its assistance in providing data for the development of this work.

This study was financed in part by the Coordenação de Aperfeiçoamento de Pessoal de Nível Superior - Brasil (CAPES) - Finance Code 001.

\section{References}

Arenales M, Armentano V (2015) Pesquisa Operacional para cursos de engenharia. São Paulo: Elsevier. 1342p.

Associação Catarinense de Empresas Florestais ACR (2019) Anuário estatístico de Base florestal para o estado de Santa Catarina 2019. Florianópolis: ACR. 118p.

Heinrich D (2010) Simulação da produção de madeira serrada. Dissertação, Escola de Administração, Universidade Federal do Rio Grande do Sul. 159p.

Hillier FS, Lieberman GJ (2012) Introdução à pesquisa operacional. 9. ed., São Paulo: Mac Graw Hill. 1028p.

Indústria Brasileira de Árvores - IBÁ (2019) Relatório 2019. Brasília: IBÁ. 80p.

Lengowski EC, Fuck SC, Bonfatti Junior EA (2017) Estimativa do ganho em rendimento no desdobro da madeira de Pinus spp. utilizando modelagem. In: III CBCTEM, Florianópolis, Brasil.

Murara Júnior MI, Rocha MP, Trugilho PF (2013) Estimativa do Rendimento em Madeira Serrada de Pinus para Duas Metodologias de Desdobro. Floresta e Ambiente, 20(4):556-563.

Murara Júnior MI; Pereira MR, Romano TJ (2005) Rendimento em madeira serrada de Pinus taeda para duas metodologias de desdobro. Revista Floresta, 35(3):473-483.

Poldi KC, Arenales MN (2010) O problema de corte de estoque unidimensional multiperíodo. Pesquisa Operacional, 30(1): 153-174.

Tomaselli I (2000) Tecnologia da madeira no Brasil - Evolução e Perspectiva. Revista Ciência e Ambiente, 20:101-112.

Ulbricj G, Ribeiro R (2010) Otimização de produtividade em prensas de alta frequência utilizando ferramentas da programação linenar - um estudo de caso. Ágora, 17(1):171-183.

Vital BR (2008) Planejamento e operações de serrarias. Viçosa: Editora UFV. 211p. 